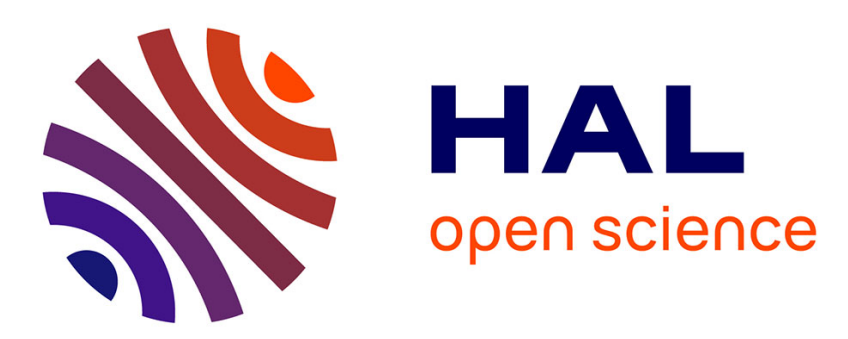

\title{
Erratum to "Uncertainty in open-channel discharges measured with the velocity-area method [Flow Meas. Instrum. 26 (2012) 18-29]"
}

\author{
J. Le Coz, B. Camenen, X. Peyrard, Guillaume Dramais
}

\section{To cite this version:}

J. Le Coz, B. Camenen, X. Peyrard, Guillaume Dramais. Erratum to "Uncertainty in open-channel discharges measured with the velocity-area method [Flow Meas. Instrum. 26 (2012) 18-29]". Flow Measurement and Instrumentation, 2015, 46, pp.193-194. 10.1016/j.flowmeasinst.2014.07.004 . hal01247948

\section{HAL Id: hal-01247948 \\ https://hal.science/hal-01247948}

Submitted on 23 Dec 2015

HAL is a multi-disciplinary open access archive for the deposit and dissemination of scientific research documents, whether they are published or not. The documents may come from teaching and research institutions in France or abroad, or from public or private research centers.
L'archive ouverte pluridisciplinaire HAL, est destinée au dépôt et à la diffusion de documents scientifiques de niveau recherche, publiés ou non, émanant des établissements d'enseignement et de recherche français ou étrangers, des laboratoires publics ou privés. 


\title{
Erratum - Uncertainty in open-channel discharges measured with the velocity-area method (2012)
}

\author{
J. Le Coz ${ }^{\mathrm{a}, *}$, B. Camenen ${ }^{\mathrm{a}}$, X. Peyrard ${ }^{\mathrm{a}}$, G. Dramais ${ }^{\mathrm{a}}$ \\ ${ }^{a}$ Irstea, UR HHLY, Hydrology-Hydraulics \\ 5 rue de la Doua CS70077 69626 Villeurbanne cedex, France
}

Several formal mistakes can be found in the research paper published by Le Coz et al. [1] in Flow Measurement and Instrumentation. Their conclusions on the introduced method are still valid but the following errors may be detrimental to its correct implementation by others.

As stated in the original paper, uncertainty components written $u(X)$ are relative standard uncertainties (in \% of measurand $X$ ). Therefore, the right-hand terms of Eqs. 12, 14, 15 and Eq. 16 should be divided by $D_{i}$ and $V_{i}$, respectively. In Eqs. 14 and 15, the 'mid-section' and 'mean-section' mentions should be inverted. The presented results were not affected by these typos.

Two additional mistakes were actually included in our computations. The uncertainty component, $u_{s}$, accounting for systematic errors remaining after the best calibration of velocity, width and depth measuring devices was neglected in the application of Eq. 11, instead of being set to $1 \%$ as announced. This slightly affected the lowest uncertainty estimates, that typically cannot be lower than $2 \%$. The main mistake lies in Eq. 15 where 8 should be replaced by 4, which means that the uncertainty components $u_{m}(D)$ were systematically underestimated in the presented results. Whereas it was previously obtained to be equivalent to $u_{m}(V)$, it is actually now twice bigger than $u_{m}(V)$, on average. This seems realistic since the transverse velocity profile is usually smoother than the bed profile.

The correct expressions for Eq. 14 and Eq. 15 are:

$$
\begin{array}{ll}
u_{m}\left(D_{i}\right)=\frac{b_{i}}{4 \sqrt{3} D_{i}} \tan \alpha & \text { (mean - section) } \\
u_{m}\left(D_{i}\right)=\frac{b_{i+1}^{2}+b_{i}^{2}}{4 \sqrt{3} D_{i}\left(b_{i+1}+b_{i}\right)} \tan \alpha & \text { (mid - section) }
\end{array}
$$

The corrected values of Table 2 in the original paper are presented in Tab. 2. Additional columns for $u_{s}^{2}$ and $u_{c, e}^{2}$ were included since these terms are no longer negligible for several cases. Typically, $u_{s}^{2}$ contributes for almost half of the variance for the measurements in the artificial canals (Gignac and Laboratory flume).

\begin{tabular}{c|c|c|c|c|c|c|c|c|c|c|c} 
& $B / D / m$ & $\begin{array}{c}\text { max. } \\
\text { slope }\end{array}$ & $\alpha$ & $\begin{array}{c}\boldsymbol{U}(\boldsymbol{Q}) \\
\text { (new) }\end{array}$ & $\begin{array}{c}u_{s}^{2} \\
(\text { ratio) }\end{array}$ & $\begin{array}{c}u_{c, e}^{2} \\
\text { (ratio) }\end{array}$ & $\begin{array}{c}u_{m}^{2}(V, D) \\
\text { (ratio) }\end{array}$ & $\begin{array}{c}u_{p}^{2} \\
\text { (ratio) }\end{array}$ & $\begin{array}{c}u_{e d}^{2} \\
\text { (ratio) }\end{array}$ & $\begin{array}{c}\boldsymbol{U}(\boldsymbol{Q}) \\
\text { (ISO748) }\end{array}$ & $\begin{array}{c}u_{m}^{2} \\
\text { (ratio) }\end{array}$ \\
\hline Arc & 5.0 & $15^{\circ}$ & $15^{\circ}$ & $\mathbf{1 0 . 4 \%}$ & $0 \%$ & $0 \%$ & $95 \%$ & $5 \%$ & $0 \%$ & $\mathbf{5 . 2 \%}$ & $77 \%$ \\
Ardèche & 0.5 & $41^{\circ}$ & $40^{\circ}$ & $\mathbf{5 . 0 \%}$ & $16 \%$ & $5 \%$ & $74 \%$ & $6 \%$ & $0 \%$ & $\mathbf{5 . 1 \%}$ & $82 \%$ \\
Gignac & 0.2 & $0^{\circ}$ & $10^{\circ}$ & $\mathbf{2 . 9 \%}$ & $48 \%$ & $12 \%$ & $2 \%$ & $23 \%$ & $12 \%$ & $\mathbf{1 3 \%}$ & $98 \%$ \\
Laboratory & 0.6 & $3^{\circ}$ & $5^{\circ}$ & $\mathbf{3 . 0 \%}$ & $44 \%$ & $0 \%$ & $2 \%$ & $34 \%$ & $17 \%$ & $\mathbf{3 . 5 \%}$ & $60 \%$ \\
Doller & 1.7 & $14^{\circ}$ & $15^{\circ}$ & $\mathbf{7 . 7 \%}$ & $7 \%$ & $15 \%$ & $74 \%$ & $2 \%$ & $1 \%$ & $\mathbf{9 . 8 \%}$ & $90 \%$
\end{tabular}

Table 2: Results of the uncertainty analysis of the stream discharge measurements test cases (after correction).

\footnotetext{
${ }^{*}$ Corresponding author. Tel: +33 472208786; fax: +33478477875

Email address: jerome.lecoz@irstea.fr (J. Le Coz)
} 


\section{Acknowledgements}

We are grateful to Aurélien Despax (LTHE, EDF) and Pierre-Marie Bechon (DREAL Rhône-Alpes) who contributed to the identification of errors in the published article.

[1] J. Le Coz, B. Camenen, X. Peyrard, and G. Dramais. Uncertainty in open-channel discharges measured with the velocity-area method. Flow Measurement and Instrumentation, 26:18-29, 2012. 